\title{
THINKING BEYOND 'ENGINES OF GROWTH': RE-CONCEPTUALIZATION URBAN PLANNING DISCOURSE IN PAKISTAN
}

\author{
Nausheen H. Anwar*
}

\begin{abstract}
Ring towns, twin-cities, city regions, peri-urban, intermediate cities and more, the vast nomenclature captures the unrelenting interest in secondary cities as 'engines of growth', capable of surmounting the challenges of urbanization in Pakistan. This conceptually-driven article examines the bourgeoning interest in secondary cities and proposes alternate ways of thinking about such conurbations. It underscores the need to go beyond technocratic discourse and capitalist assumptions of infinite growth and modernization as conventionally applied in regional and urban planning discourse in Pakistan. The article calls for re-orienting planning discourse in Pakistan to incorporate the substantive theme of 'urbanism', which is crucial for comprehending how citizens experience urban life across a diverse and shifting landscape, where the city fades into the countryside, or where 'urban sprawl' and 'ribbon developments' defy categorization.
\end{abstract}

Keywords: Secondary cities, Planning discourse, Urban sprawl, Globalization

\section{INTRODUCTION}

In the alpha, beta, gamma pecking order of global cities ${ }^{1}$ understood as the command and control points of the world economy and finance capital, secondary cities tend to occupy the lower rung of a Darwinian hierarchy or fall through the cracks of a system of representation that has valorized cities in terms of modernization theories of the post-WW 2 era. Put differently, a city's success is measured in terms of its participation in globality or its ability to survive in the competition of network capitalism. The inverse or lack of such participation and failure to survive necessitates stagnation, impoverishment or even a pathological condition. Such ideas are pervasive in urban planning discourse in
Pakistan where a model of development similar to the prototypical Western global city dominates (Shatkin 2007), albeit with diverse applications and outcomes. An article in a leading Pakistani journal (Shakir, 2012) summarized the priorities for a modern city, underscoring its ability to spur on the development of the hinterland through the workings of a modern state that conjures the global city "... as a catalyst for the growth of the region as a whole". The implicit assumption being if state functionaries transform key metropolitan centers into global/world cities, then the benefits of such transformation axiomatically flow across secondary cities and beyond, reviving and revitalizing the languishing hinterland. Such discourses also pivot on reductive explanations of Pakistani cities in general. They invoke the idea that the 'secret' to resolving urban problems lies in 'unlocking Pakistan's urban economy' so it can attract the 'right' human talent and appropriate capital (Dawn 2012). That such discourses materialize within the spaces of uppermiddle class privilege and are aligned with neoliberal agendas is hardly questioned.

Whither then the secondary city? In recent discourse, for instance in the World Bank's influential Urban \& Local Government Strategy: Concept and Issue Note (2009) secondary cities are understood as the driving force of urban population growth. Notwithstanding the importance of such discourse, the Bank's language of scientific/economic efficiency consigns cities' futures to a series of tips analogous to financial portfolio management: "...a portfolio of places...so as to maximize the benefits of agglomeration economies, while ensuring a smooth urban transition." Such corporatist visions of alignments, overhauls, sector strategies and harnessing productivity either deliberately overlook the critical role of political economy, colonial legacies and political struggles, or view these issues through the narrow prism of external/internal risk mitigation. Ash Amin (2004) has correctly asserted that such interpretations assume

* Dr. Nausheen H. Anwar, Assistant Professor of Urban Studies, Department of Social Sciences \& Liberal Arts, Institute of Business Administration (IBA), Karachi and Post doctoral fellow, at Asia Research Institute, National University, Singapore.

1 I have not included in this hierarchy the 'megacity' and its critical inter-dependence with the global city. A sophisticated account of this conceptual dynamic is provided by Roy (2011) Slumdog Cities: Rethinking Subaltern Urbanism. International Journal of Urban and Regional Research, 35(2): 223-238. 
territories can be controlled and managed and politics can be reduced to a mere case of 'cadre managerialism'. ${ }^{2}$

In a similar vein, in the Asian Development Bank's (ADB 2008) project report that is a commendable effort focused on 'sustainable development' ${ }^{3}$ through upgrading urban transport, water sewage systems and solid waste management, the secondary city in Pakistan is put center-stage. By channeling investments into Sindh's cities such as Sukkur, Rohri, Shikarpur, Larkana and several others, the ADB project endeavors to address the needs of approximately six million persons residing in peripheral settlements. Such reformist interventions strive to transform secondary cities into economically vibrant nodes that are desirable destinations for finance-business capital. The implicit assumption here is that by reforming secondary conurbations new pathways will emerge to transform 'lagging' cities into 'engines of economic growth'.

A similar outlook was proposed in the Planning Commission's Task Force Report on Urban Development 2011 wherein the primary role of towns and cities is cast as 'engines of economic growth and social change'; engines that can surmount the challenges of urbanization and are also generative of 'creative cities' and 'smart cities'. While the multipronged agendas articulated in such reports and projects correctly promote devolution processes and delineate clear roles and responsibilities in urban service delivery in secondary cities, the conceptual framework, nevertheless, is tied to an economic discourse that reifies urban planning practice in terms of scientific objectivity and political impartiality. Such economic mantra naturalizes the workings of a particular type of political-economic system (neoliberal politics, neoclassical economics) by repeatedly relating interchangeable terms such as efficiency, productivity, and competitiveness.

Broadly speaking, the 'secondary city' has been categorized as the nexus between rural and urban areas. Typically these are former rural villages or historic trading and administrative centers transformed into peri-urban settlements where precolonial administrative structures are maintained or where people continue to work on farm land but where populations have quadrupled. The development of this category of cities has been understood as a means to revitalize the economies of surrounding rural areas and to control migration into larger cities or primate cities. While in Pakistan, certain authors (Kumar 2014) emphasize the topographical and demographic forces and related factors in defining the secondary city, in this article I push for a more nuanced approach. Rather than understanding cities through the reductive lens of economics and demography or through the primate-secondary or global-secondary binaries, I believe secondary cities should be understood as heterogeneous sites in which new forms of urban life are being imagined and shaped.

In juxtaposing the discourse of the 'global/world class city' and the 'secondary city', my objective is also to underscore that these are essentially two sides of a coin buttressed by a paradigm in which a successful city is understood in terms of infinite growth and economic modernization, or through a lens that celebrates a Western modern aesthetic. My aim is not to denude the importance of secondary cities as these can play a positive role in prescriptive terms, but more so to underscore the limits of a discourse that imagines a potentially better urban future through the narrow prism of technical advancements, economic efficiency and expert administration of a system or portfolio of cities (World Bank 2009). Such conceptualizations that focus on issues of economic competitiveness elide the critical concerns of subject making, politics and human agency that are negotiated in place. Cities are more than just aggregates of economic exchange or sites locked in a perpetual competition for scarce resources put right through better urban management capabilities (ADB 2008) or human talent (Dawn 2012) or good governance (Kumar 2014). Cities are also producers of citizenship and enable us to imagine planning practice through alternate lenses that are not truncated by consigning futures to the limited imaginings of developmentalist or technocratic interventions. I believe the time has come for Pakistan's urban planners (I refer here to a newly emergent generation) to push the limits of their imaginations especially since the 'problem' of urban development has finally burst upon the scene from multiple directions. Pakistan is considered as having the highest rates of urbanization in South Asia, with a projected population of 335 million by 2050 , and an annual urbanization rate of $3.06 \%$. In Sindh and Punjab almost half the populations are already urbanized, while in Khyber Pakhtunkhwa and Baluchistan the level is

2 For an excellent critique of contemporary experiments in devolution, economic localization, clusters, and assemblies, see Amin, Thrift and Massey (2003).

3 The goal of 'sustainable development' was popularized by the publication in 1987 of the Brundtland Report following which many planning authorities across the United Kingdom and Europe enthusiastically implemented policies for sustainable urban forms. For a trenchant critique of the flawed paradigm of urban sustainability see Eric Swyngedouw (2007a). 
significantly lower ( $16.87 \%$ and $23.89 \%$, respectively), but catching up.

In what follows I first discuss the secondary city in the context of a discourse whose genealogy can be traced to a functionalist economic paradigm prevalent in the 1970s. I then problematize this discourse through the lens of urbanism, which necessitates a sociological-anthropological understanding of cities. Though this lens, we can interrogate how cities in general produce a distinct way of life; how social and spatial patterns are maintained in the context of an urban condition; how the urban might represent a new phase of historical transition in which the city may no longer be a useful unit of analysis. I conclude this essay by revisiting the question of how we can theorize/think the role of the secondary city in Pakistan's planning discourse, or more to the point, can we re-imagine Pakistan's planning discourse beyond the 'empty signifiers' (Swyngedouw 2007a, 2007b) of world-class/creative/smart/sustainable cities or a portfolio of dehumanized places?

\section{Secondary City in Modernization Discourse}

In the functionalist model of regional development and planning (Johnson 1970; Berry 1972; Rondinelli \& Ruddle 1978; Rondinelli \& Evans 1983), of the 1970s the improvement of secondary or intermediate conurbations to counter the primate city and produce an 'optimal urban hierarchy' was a subject that received extensive scholarly attention. The discourse was firmly embedded in a prior genealogy pertaining to theories of economic polarization, central places, and modernization that had emerged in the 1950s and 1960s or in the post-WW 2 era. Since there is limited space in this article to discuss key aspects of these theories, I will underscore a general truism that attributed a positive role to public organizations and thought little of the role of politics in the development of a new urban schema. Regional development and planning found expression in two significant aspects: first through growth center and second through rural service center strategies concerned with growth in industrial production and distribution, administration, and in services. Rural centers especially were considered 'engines of growth' whose development as market and service centers would increase productive capacities and promote commercialization and agricultural specialization in the broader context of national economic development. Eventually with proper planning these rural centers would become catchments brimming with employment opportunities, a policy outcome that would also counter the exodus of migrants to primate cities. The rationale behind this conceptual/theoretical wisdom was predicated on the failure of past economic strategies whose concerns with economic growth were deemed narrow, or specifically those strategies that sought to transplant largescale, export-oriented capital intensive industries into a limited number of centers. Subsequently, public funds were not only allocated to national but also to regional development agendas that incorporated secondary or intermediate regions. However, regions remained subordinate to national growth objectives and were understood as open systems that would eventually integrate into the national economy (Friedmann \& Weaver 1979). Various countries in Africa, Latin America and in Asia implemented regional development policies that were based on the growth center strategies model. In countries such as Indonesia, Kenya and Colombia the central place model exerted considerable influence on regional planning and on the spatial restructuring of territories (Taylor 1974; Appalrayu 1976).

By the mid-1970s, the functionalist approach to understanding secondary cities in regional development had been denounced for its inattention to issues of political-economy and for the overall limited success of regional development projects. Much of this criticism emerged from the Marxist 'dependency school', which focused on the exploitative nature of capitalism and on the process through which regional development policies reinforced existing power structures. In other words, by overlooking the importance of 'vested interests' regional development policy engrossed in the morphological and economic transformation of growth centers and central places had failed to consider how these very nodes were embedded in structures of power in the developing world. Even though envisioned as dynamic growth centers, smaller conurbations continued to serve the interests of political and commercial elites at the national scale. For instance, certain authors (Schatzberg 1979) posited in countries such as Zaire it was better to have a minimal number of secondary cities as these created a negative impact on rural development. The major truism attributed capitalist expansion as a causative feature in the progressive impoverishment of peripheral towns and cities. Consequently, the potentially innovative secondary city was understood as parasitic and exploitative. This interpretation was eventually deemed as a tautological and mechanistic explanation akin to a theory of class exploitation.

In recent years scholars have acknowledged that the internal dynamics of capitalist exploitation and attendant impacts on secondary cities are considerably more complex than first imagined. Notably, research on the issue of labor mobility in Africa and South East Asia demonstrates a circular logic of rural-urban migration, a process that ensures 
a portion of the drained surplus to primate centers filters back into secondary regions without exerting an adverse impact on rural development (Hugo 1982). New conceptual frameworks of regional development and the role of secondary cities now emphasize the dependency relations of different geographical scales or an 'interdependent development' or for instance the need for institutional reforms to facilitate production. Moreover, scholars have called for more empirical evidence and denuded a straightforward blueprint for regional development. This is significant as regional development policies that focus on secondary cities in an effort to limit urbanization have tended to fall flat. For instance, in the 1980s the Egyptian government built cities in the desert to ease pressure on Cairo. Fast forward two decades the new towns have managed to attract less than one million inhabitants, a figure that falls well below the projected mark of five million.

Recent empirical evidence suggests that most urban growth across the global South and over the next twenty-five years will occur in smaller cities and towns (Cohen 2004). Besides, this pattern will most likely make redundant the traditional distinction between rural and urban. An important point articulated in new research is that this growth should not be attributed solely to rural-urban migration, but also to the annexation and reclassification of agricultural land as urban. This resonates with emergent trends in Pakistan in cities like Karachi concerning the transformation of vacant agricultural land in peripheral territories such as Gadap Town. For Karachi, some urban planners posit that approximately half of the population resides more than 10 $\mathrm{km}$ from the city center (Qureshi 2010), and those areas may not have been counted as urban in official censuses or research, but the lives of these residents are almost certainly urban in character.

In the 1981 Census the definition of 'urban' changed, to include only areas designated as part of municipal corporations and cantonment boards. In the province of Punjab, this change in definition led to approximately 1462 communities with populations exceeding 5000 being classified as rural, when perhaps they should have been counted as urban. In cities like Lahore, new administrative boundaries did not account for contiguous small towns that enjoy strong economic and physical linkages with urban centers. If these populations had been added, Lahore's overall population estimate would have jumped from 5 to 7 million people (Ali 2003). Therefore there is arguably an underrepresentation of the urban, which has socio-economic and political consequences. In Pakistan, the 'urban question' remains a contentious one. This is not only due to methodological conundrums about defining the 'urban', but also such classification entails important outcomes for the national political-economy. An accurate picture of urbanization in Pakistan is unlikely, even though small towns and urbanizing rural areas are systematically misrepresented as rural. The methodology for classifying the 'urban' has important implications for the national political landscape, in terms of job quotas, electoral constituency delineations, and formal municipal governance structures.

Research on Pakistan's urban condition has posited that rural settlements are no longer isolated in the traditional sense, or as some authors (Qadeer, 2000) assert: "It is becoming difficult to differentiate urban from rural areas. The homogenizing influences of the nation-state, the industrial mode of production and the communication revolution have almost eliminated conventional differences." In the northern and central parts of Punjab, secondary /intermediate cities have emerged as industrial and service centers in the midst of agricultural regions, and in the Khyber Pakhtunkhwa, cities such as Peshawar have flourished as centers of smuggled goods and contraband items linked with the dynamics of the Afghan wars.

Are Pakistani cities a case of 'fragmented' or 'splintered urbanism' where upscale, planned cosmopolitan neighborhoods and shopping plazas are juxtaposed with the informal katchi abadi or the 'slum-dog' city? To what extent are these territorial/spatial communities connected and/or disconnected? Are these splintered spaces co-constitutive in the production of space? What mediates this relationship? How are these spaces expressions of class power? These are questions of pressing concern because they draw attention to key features of urbanism such as modes of social regulation and the production of spatial value. For instance, Roy (2005) reminds us that informality as a mode of production of space cannot be essentialized as a marker of 'backward' economies but should be understood as a capitalist mode of production. Pakistan's current urban transition and those of cities across the global South differ to some extent from the European and American experiences of the early 20 th century. Notably, in comparison to Western counterparts urbanization across Pakistan is taking place at a swift pace and that too in the context of low per capita income levels. Scholars understand this as a process detached from the conventional process of economic development.

Moreover, the nature of urban change has become more complex today due to its interdependence with the global economy, for instance the emergence of a new international division of labor, transnational communications, cross-border 
alliances between businesses, and new opportunities for wealth creation. There is also a growing convergence in rural-urban lifestyles that are making the traditional distinction between rural and urban a problematic. Writing on the changing nature of secondary cities in Sindh in Pakistan, certain authors (Arif \& Raza, 2009; Rind, 2014) underscore that the dynamic of urban sprawl is increasingly difficult to contain through land control mechanisms. They cite the role of politics as a vital factor influencing land allocation decisions. From Tando Allayar, Shikarpur, Nawabshah to Sanghar, Mithi, Matiari, Umerkot and more, secondary cities are being subsumed by urban sprawl, and agricultural land on town fringes is being swallowed up the demand for housing. Migration to small towns is another dynamic that undergirds socio-economic change and pivots on geographical factors, climate change, historical trends and colonial interventions that have changed land ownership patterns and ecological conditions in certain parts of Sindh (SPDC 2015; Arif \& Manzoor 2009).

Such challenges for cities are also fittingly emphasized by other authors (Ahmed \& Altaf, 2013) who have pushed for a political-economic understanding. Still, the analytical tone in most interrogations of the urban (Kumar, 2014) remains staunchly technocratic and de-politicized. Moreover, the secondary-primate binary is shot through such discourses where the 'problem' of the secondary city is expected to be resolved through a 'balanced' set of policy measures. While it is not my intention here to take away the importance of such studies, I wish to underscore that they are representative of the dominant discourse on urban planning in Pakistan.

Within the changing rural-urban continuum in Pakistan, new networks are also emerging that extend beyond the conventional limits of secondary conurbations. What do such changes entail in terms of understanding how urban life is being re-shaped and re-imagined? In the early $20^{\text {th }}$ century Ferdinand Tonnies' famous typologies of Gemeinschaft and Gesellschaft as two contrasting models of pre-industrial and industrial society enabled scholars to make sense of the profound changes that had swept across $19^{\text {th }}$ century Europe. Tonnies was deeply pessimistic about the consequences of those changes and feared a breakdown of traditional social order, thus seeing Gemeinschaft as a source of stability in society. Tonnies was not referring to a mere change of physical setting but more so how our sense of place is predicated on social organization. Thus in the Gemeinschaft typology a sense of place was reflected in a notion of 'community ${ }^{4}$ of blood' (kinship) and a 'community of mind' (friendship). How then should we investigate the nature of urban change in Pakistan? How can we envisage a 'living community' in the context of the divided, fragmented, splintered, and violent modern city? How should we contextualize the increasingly complex dynamic that is the rural-urban continuum? To what extent can urban planners engineer, if desirable, a sense of community in the context of larger social forces and changing social compositions? In posing these questions I wish to underscore the crucial need to push beyond the limits of conventional planning discourse that comprehends urbanization/urban development as a dysfunctional physical phenomenon put right through improved physical administration, technical progress and/or economic development. In endeavoring to understand the dynamics of urban change, it is important to also remain attentive to issues of 'urbanism', specifically as a way of life rather than just a physical, morphological, demographic and technocratic phenomenon.

\section{Novel Agendas}

Perhaps the richest and most thought provoking interventions on urbanism have emerged in Africa and Latin America where there has been considerable scholarly attention directed toward wide ranging themes on secondary cities, urban primacy, and infrastructures, new pathways of capitalist accumulation and on conditions of urban citizenship. Particularly, the richness of the emerging debate is captured through a multidisciplinary lens that applies sociological, urbanist, and anthropological approaches for comprehending the complex and at times contradictory consequences of urban change. Seventeen of the world's fastest-growing cities with populations of more than one million are situated in Africa. African cities have always been understood as distorted and parasitical spaces (Simone 2009). Nevertheless, it is in Africa where we can see not only the rapid flow of migrants into city centers but also an increased transformation of small cities that serve agricultural needs and act as service centers.

4 I acknowledge here that there is little certainty over the meaning of community whether in Tonnies' work or elsewhere. Community is a complex and inherently ideological concept. At the very least we can say that a longing for community suggests a desire for security and identity or for a 'good life'. In this sense, we approach the concept of community as a normative prescription. For an interesting treatment of this thorny subject see Setha Low's (2001) discussion on gated communities and social fragmentation, and Richard Sennett's (1997) cautionary account of communal coercion and illusion.

Journal of Research in Architecture and Planning: Vol. 15, 2013 (Second Issue) - Architecture, Urban Design \& Planning 
In his book For the City Yet to Come, AbdouMalik Simone (2004) places African cities as exemplars of urbanism rather than as just oddities or failed economic engines. Focusing on new quarters or secondary settlements such as Douala in Cameroon and Winterveld near Pretoria, Simone examines the daily lives of the communities and aspects of development policies. Simone's objective is to theorize in new ways the African city that has always been understood as one that 'doesn't work'. A different way of understanding necessitates that we re-consider concepts such as illegal/legal and formal/informal in an attempt to define different types of urban configurations and experiences. He asserts:

"I attempt here to add a new dimension to urban analysis by concentrating on particular aspects of individual and collective behavior outside of the conventional contexts of household, institution and quarter. I believe that these 'outsides' are important domains and considerations for understanding African cities as more than 'failed cities'.....If the limited resources deployed for urban development in Africa are to be effective, it is important to make common cause with the daily efforts of African urban residents. This is a common cause about using the city as a generator of imagination and wellbeing..... the only way to make such common cause is to amplify the sensibility, creativity, and rationality of everyday practices and behaviors that either are invisible or appear strange."

Research on secondary cities (Boeck et al 2009) in Africa has examined how these 'not yet cities' generate networks and practices that extend well beyond their local limits and that too in ways that are more successful than their larger counterparts: "The secondary city obeys to a specific 'situationist' logic which often goes against the interests of the nation-state or the main urban centers that embody the state. In other words, such secondary urban centers are important laboratories for the definition of identity around religion, nation, ethnicity and locality." (Boeck et al 2009). The objective here is to highlight the "thickening of urban articulations' and the level of agency that resides in specific urban contexts. In Latin America where there has been considerable interest in theorizing and generating empirical research on issues of urban citizenship (Holston 2010), marginality (Perlman 2010) and spatial segregation (Caldeira 2000), the overarching questions concern how the urban poor or the marginalized appropriate space and livelihood, and to what extent the recent rise of leftist populism in countries such as Brazil and Venezuela can remedy the issue of poverty in urban-rural contexts.
Latin American theorizing on the planning and development of cities (mega-city or secondary) connects with the legacy of the dependency theorists (Cardoso \& Faletto 1979; Amin 1976; Frank 1970) who asserted that the persistence of poverty in the 'underdeveloped world' and the parasitic primate city were consequences of dependency through which Latin America had been coercively inserted into the world economy. Later it was Manuel Castells (1983) who catalyzed the idea of the 'dependent city' as a space of social mobilization but where the politics of patronage are endemic and often undermine political struggles.

How should we describe Pakistani cities that lie beyond the fantasies of the world city/global city? Specifically those cities that do not fit into tidy distinctions derived from western modernization and urban theories; those cities many secondary/peripheral conurbations - that are viewed as inefficient, low technology, non-commodified and unconnected to global capitalist markets? Such cities do not merit attention as they do not fit the language used to describe the 'global city', i.e., "wonder, speed, diversity, density, verticality, innovation" (Robinson 2004). For certain scholars (Robinson, 2004) the ordinary cities or forgotten places cannot be understood on the basis of the singular binary grid of 'modern' versus 'backward'/ 'primitive' as conventional discourse has allowed. Such discourse has been criticized for an urban theorization curtailed by developmentalism, and which has produced a view of the West as modern by de?ning its 'others'; cities and people who are not viewed as modern, and therefore are excluded as potential sites for ways of understanding the urban condition.

How should we bring such cities back onto an intellectual grid that is not trapped in conceptual frameworks activated by a colonial way of thinking? In Pakistan, planning discourse has turned keenly toward the 'world city' as a benchmark of progress and development. We can see this articulated, for instance, in municipal documents like the Karachi Strategic Development Plan 2020 wherein "world cities are characterized by minimal poverty and slums" (CDGK 2007:3). We can also see this in the visions touted by the new urban planners of the $21^{\mathrm{st}}$ century, private developers like Malik Riaz and his ilk. Such visions about new urban futures are an embodiment of a speedy, seamless $21^{\mathrm{st}}$ century urbanization and globalization as measured for instance by Singapore or Dubai. The indiscriminating acceptance of such concepts suggests an underlying assumption that the aesthetic such configurations embody are in fact desirable. The desires of city governments in Karachi and Lahore and those of a certain class of citizens are aligned with a western 
modern aesthetic that sees merit in engineering spaces far removed from the threat of social contact especially between persons from different classes. We can observe this aesthetic expressed in the construction of the Lyari Expressway that rides over the embankments of the Lyari River bed and bypasses decades old settlements now deemed an embarrassment and threat to Karachi's modernization.

Expressways or highway routes and new securitized (sanitized) development schemes are transient spaces meant for circulation, consumption and communication (Auge 2008). These spaces are not defined in terms of their relational or historical identity but are instead a world where we surrender to 'solitary individuality' (Auge 2008). In the words of the sociologist Richard Sennett (1990), these are spaces that embody a 'neutralised city' or one that lies within the circuits of commodity value. Hence, spaces that lie outside of the commodity aesthetic or world-class imaginations are devalorized spaces. The concept of the neutralized city can also be understood in a different way, notably through the idiom of the 'sustainable city' which "promotes a market-led, technocratic approach to 'greening' capitalism and almost completely ignores issues of social justice and the processes of social inclusion and exclusion that run through urban environments and the very technological advancements they are advocating" (Swyngedouw 2007a). Hence, the neutralized city is also one where there is silence concerning inequality. Democracy then is tantamount to an 'empty signifier' that is effortlessly attached to the diverse nomenclature of the sustainable city, the creative city, the smart city or the world class city. The smart city especially is the new utopia and in Pakistan there is increasing talk in the media concerning its arrival; the commitment to "make Karachi smart and turn it into a city of lights" (Dawn, 2015). What then of populations who live in the margins of the 'smart city' and whose experiences of everyday life pivot on technological disintegration and infrastructural disconnect? Where are their futures consigned in spatial and social terms? Such talk of smart cities signals a politics of consensus led by a public-private elite who know in advance the outcome of policymaking. Moreover, such visions show a total disregard for everyday power relations within and beyond cities.

A first step toward a critical reading of a Western-centric approach is to jettison the obsessive need to apply binary oppositions of backward-modern, global-local, rural-urban and creative-imitative that has pushed a generation of urban planners in Pakistan toward embracing a rank ordering perspective. As certain authors (Robinson, 2008) correctly assert all cities are ordinary spaces that also happen to be innovative or are parts of the same field of analysis. This does not mute difference but denudes a neat allocation in accordance with pre-given classifications. Authors also fittingly observe that we need to get away from such a perspective because it ends up justifying a range of interventions that have deep political (imperialist) implications. Moreover, such binaries encourage a way of understanding the city as a site of modernity and the rural/peripheral or secondary city as primitive. Such conceptualizations limit and conceal the diversity of spaces/places in which the modern and the traditional are mutually interdependent, or in which a series of transactions connect different economies and spaces to one another (Roy 2005). A different approach comprehends that "what is at stake is believing that all cities ought to have the right to shape distinctive futures whatever power position they hold in relation to other places" (Fraser 2006). This extends not only to the management of cities and their economies, but also to the diversity of persons that reside within.

\section{CONCLUSION}

I have attempted in this article to give some indication of the complexities of current reconsiderations of urban planning discourse as it relates to the role of secondary cities (and generally all cities) in Pakistan. I have also highlighted the modernization driven discourse on the secondary city, notably its distinctive 'functionalist' legacy that underpins the resurgent interest, especially in Pakistan where the dominant lens still remains embedded in economics. My underlying objective has been to demonstrate that the problematic of the secondary city is not just about the absence of good governance or weak productivity/efficiency and competitiveness, but of a modernist discourse that should be re-conceptualized to see ALL cities as active relational processes. In advocating this position, I am not against a project of devolution that is committed to the construction of regional representation and improvement of urban services in secondary cities. Rather, I have a problem with a type of thinking that assumes (a) a given geographical territory can be effectively managed and controlled, and (b) this is possible through pro-devolution institutions and technocratic managerialism. What is envisioned in such thinking is a restrictive democracy that does not fully engage with the different spatial registers of the politics of a given place.

Pakistan's dominant planning discourse is embedded in a technocratic-modernist style that is inadequate for understanding the contemporary dynamics of urban life in the $21^{\text {st }}$ Century. Moreover, the absence of human agency, which is a key feature of such discourse, dehumanizes 
planning practice and renders the political-economic world as a process that can be determined by self-evident economic/technocratic laws. Rather than being cast as 'failed cities' or 'ungovernable cities' waiting to be reshaped into world-class conurbations or engines of growth, a view prevalent amongst planners and government functionaries and even academics, we should endeavor to conceptualize in ways that reveal the potential of all cities in terms of their particular resources, or to understand them as places in their own right. Certain authors (Roy 2009) correctly observe that in the global South the 21 st century conurbation "makes a fool of census jurisdictions, of the mappings of city and suburbs, and confounds the easy narratives of regional change, including those that emphasize agglomeration and innovation." Is the secondary city today a 'post-border city'?

A final point I wish to make is that cities everywhere are permanent cultural revolutions (in a Lefebvrian sense) and if there is a defining quality of life, then it is always in a positive sense incomplete. Cities are more than just 'networks of concrete becoming' (Boeck et al 2009). They are founded on the heterogeneity of cultural, institutional, social and political-economic assets and complex histories. Cities are agglomerations that go beyond material infrastructure and physical site. As Boeck posits built form may be "produced randomly in human sites as living space." (2004: 233). I conclude then with a call to rethink planning discourse in Pakistan; beyond material forms of morphological representation and conventional developmentalist/ technocratic aspirations. I invite a new generation of urban planners, young, vibrant students, future trailblazers at institutions like NED University, to inaugurate a planning discourse that expresses the particular characteristics of the city as a social institution and as a form of human agency and association, and above all as a site where the quest for social and territorial justice is permanently fixed centerstage.

\section{REFERENCES}

Ali, R. (2003) Underestimating urbanization. S. A. Zaidi (ed.) Continuity and change: Socio-political and institutional dynamics in Pakistan. City Press: Karachi.

Amin, S. (1976) 'Unequal development: An essay on the social formation of peripheral capitalism', in Monthly Review Press.

Amin, A., N. Thrift and D. Massey (2003) Decentering the Nation: a Radical Approach to Regional Inequality. Catalyst, London.

Appalrayu, J. (1976) 'Growth-Centre Strategies in Less-Developed Countries', in Alan Gilbert (ed.) Development Planning and Spatial Structure, pp: 143-67. London: Hutchinson.

Arif, H. and M. Raza (2009) Migration and small towns in Pakistan. IIED, Working Paper Series on Rural-Urban Interactions and Livelihood Strategies, Working Paper 15.

Asian Development Bank (ADB) (2008) Proposed Multitranche Financing Facility and Technical Assistance Grant Islamic Republic of Pakistan: Sindh Cities Improvement Investment Program.

Altaf, A. and N. Ahmed (2013) 'Economics of Urbanization'. The Urban Gazette, July- September, P \& D Department, Punjab.

Augé, M. (2008)ÊENon-Places: An Introduction to Supermodernity, 2nd edition London: Verso.

Berry, B.J. (1972) 'Hierarchical Diffusion: The Basis of Developmental Filtering and Spread in a System of Growth Centres', in P. W. English \& R.C. Mayfield (eds.) Man, Space and Environment, pp: 340-59. Oxford: Oxford University Press.

Boeck, F. de et al. (2009) 'The African inner city: [Re]-sourced', in African Perspectives.

(2004) Kinshasa: Tales of the Invisible City. Ghent-Amsterdam: Ludion

Caldeira, T. (2000) City of Walls: Crime, Segregation, and Citizenship in Sao Paolo. University of California Press. 
Cardoso, F.H. \& E. Faletto (1979) Dependency and Development in Latin America. University of California Press.

Castells, M. (1983) The City and the Grassroots. Berkeley: University of California Press.

City District Government Karachi (CDGK). Karachi Strategic Development Plan 2020. Karachi:

Master Plan Group of Offices in association with M/s Engineering Consultants (Pvt.) Limited and M/s PADCO - AECOM, 2007.

Cohen, B. (2004) 'Urban growth in developing countries: A review of current trends and a caution regarding existing forecasts', in World Development, 32 (1) pp: 23-51.

Dawn (2015) 'MoU signed: Karachi to start getting free WiFi, CCTV, solar-powered street lights by end of 2015. Available at: http://tribune.com.pk/story/919267/mou-signed-karachi-to-start-getting-free-wifi-cctv-solar-powered-street-lights-byend-of-2015/

Dawn (2012) 'Capturing our urban economic potential'. Available at: http://tribune.com.pk/story/363136/capturing-oururban-economic-potential/

Frank, A. G. (1970) 'The development of underdevelopment', in Monthly Review Press, pp. 4-17.

Fraser, J. C. (2005) 'Globalization, development and ordinary cities: A review essay', in Journal of World Systems Research, 12(1) pp. 189-197.

Friedmann, J. \& C. Weaver (1979) Territory and Function: The Evolution of Regional Planning. London: Edward Arnold.

Holston, J. (2010) Insurgent Citizenship and the Disjunctions of Democracy and Modernity in Brazil. Princeton University Press.

Hugo, G. J. (1982) 'Circular migration in Indonesia', in Population and Development Review, 8(1) pp: 59-83.

Johnson, E. A. J. (1970) The Organization of Space in Developing Countries. Cambridge, MA: Harvard University Press.

Kumar, R. (2014) Urban Economic Policy for Growth and Development of Secondary Cities in Pakistan. Available at $\mathrm{http}: / /$ www.indusvalley.edu.pk/library/Arch/PUF\%20EVENT/Venue\%201/All\%20Session/Session\%202/Ravindar\%20K umar/2-Paper\%20RAVI\%204\%20PUF\%202013.pdf

Lee, D. and H. Newby (2000) The Problem of Sociology. Routledge, NewYork, N.Y.

Low, S. (2001) 'The edge and the center: Gated communities and the discourse of urban fear', in American Anthropologist, 103 (1), pp. 45-58.

Perlman, J. (2010) Favela: Four Decades of Living on the Edge in Rio de Janeiro. Oxford University Press: New York.

Qadeer, M. (2000) 'Ruralopolises: The spatial organization and residential land economy of high-density rural regions in South Asia’, in Urban Studies, 37 (9), pp.1583-1603.

Qureshi, S. (2010). The fast growing megacity Karachi as a frontier of environmental challenges: Urbanization and contemporary urbanism issues, in Journal of Geography and Regional Planning, 3(11), 306-321.

Rind, T. A. (2014) Dynamics of Sprawl: Case studies of secondary cities of Sindh. South Asian Cities Conference, Pakistan Urban Forum, 9-12 January. Available at https://www.academia.edu/6050380/Dyanimics_of_Sprawl_-

_a_case_study_of_secondary_cities_of_sindh_Pakistan

Robinson, J. (2006)ÊOrdinary Cities: Between Modernity and Development. London: Routledge.

Rondinelli, D.A. and K. Ruddle (1978) Urbanization and Rural Development: A Spatial Policy for Equitable Growth. New York: Praeger.

and H. Evans (1983) 'Integrated Regional Development Planning: Linking Urban Centres and Rural Areas in Bolivia', in World Development, 11 (1), pp. 31-53.

Journal of Research in Architecture and Planning: Vol. 15, 2013 (Second Issue) - Architecture, Urban Design \& Planning 
Roy, A. (2009) 'The $21^{\text {st }}$ century metropolis: New geographies of theory', in Regional Studies, 43 (6), pp. 819-830.

(2005) 'Urban Informality: Toward an Epistemology of Planning', in ÊJournal of the American Planning Association, 71 (2), pp 147-58.

Schatzberg, M.G. (1979) 'Islands of Privilege: Small Cities in Africa and the Dynamics of Class Formation', in Urban Anthropology, 8(2) pp: 173-90

Sennett, R. (1997) The Fall of Public Man. New York: W.W. Norton.

(1990) The Conscience of the Eye: The Design and Social Life of Cities. ÊNew York: Alfred A Knopf.

Shakir, M. (2010) 'Redefining 'World City' for Karachi.' Archi Times Available at:

http://archpresspk.com/January_karachi_city.htm. Accessed January 10, 2012.

Shatkin, G. (2007) 'Global cities of the South: Emerging perspectives on growth and inequality', in Cities, 24(1) pp: 115 .

Simone, A. (2009)ÊCity Life from Jakarta to Dakar: Movements at the Crossroads, Global realities. New York: Routledge.

Social Policy and Development Center (SPDC) (2015) Gender and Social Vulnerability to Climate Change: A Study of Disaster Prone Areas in Sindh. Times Press (Pvt.) Ltd., Karachi.

Swyngedouw, E. (2007a) 'Impossible "sustainability" and the postpolitical condition', in Krueger, R. and Gibbs, D. (Eds.) The Sustainable Development Paradox: Urban Political Economy in the United States and Europe, pp:13-40. London: Guildford Press.

(2007b) 'The post-political city', in BAVO (Ed.) Urban Politics Now: Re-imagining Democracy in the Neo-liberal City, pp: 58-76. Rotterdam: Netherlands Architecture Institute NAI Publishers

Taylor, D.R.F. (1974) 'The Role of the Smaller Urban Place in Development: A Case Study from Kenya', in Proceedings of the Commission of Regional Aspects of the Development Process, meeting held at the University of West Ontario, London, Ontario, pp: 615-38.

World Bank (WB) (2009) The World Bank Urban and Local Development Strategy: Concepts and Issue Note. 